Masayuki Niino: Development of Functionally Gradient Material.

This paper discribes the development of Functionally Gradient Material (FGM) which is promoted by Science and Technology Agency with "special coordination funds for promoting science and technology" from 1987. FGM is an advanced metal/ceramic compositional gradient from a metal side to a ceramic side to obtain the function of the thermal stress reduction in the high temperatur circumstance such as aerodynamic heating or combustion chamber of space plane. The aim of the development is completion of FGM with the function to withstand $2000 \mathrm{~K}$ in the ceramic side and the difference of $1000 \mathrm{~K}$ between both sides. which are generated by the high temperature gas and the active cooling system. The small-sized FGM with a diameter of $30 \mathrm{~mm}$ and a thickness of $1 \sim 10 \mathrm{~mm}$ is scheduled to be completed by March, 1990 and the large-sized FGM of $300 \mathrm{~mm}$ by $300 \mathrm{~mm}$ with $1 \sim 10 \mathrm{~mm}$ in thickness by March, 1992. The development is shared by three research groups such as material designing. fabrication and evaluation. which consist of 30 research institutes including national institues, universities and private companies. Material design group developed expert system. Fabrication group produced small FGM test pieces by physical-chemical combination vapor deposition process. thin sheet laminatlon method. low pressure plasma spray method and self-propagating high temperature synthesis process. Evaluation group developed varlous techniques for thermal barrier performance, thermal fatigue properties, thermal shock resistance and etc. (Received December 7,1989)

\title{
1. 宇宙新時代への挑戦
}

米国のNAS P ( National Aero-Space Plane ) 計画における実呀機 X-30 に代表されるスペース プレーン（宇宙往遄機）が世界的に脚光を浴びてきており、宇宙先進諸国においてそのための基盤 技術研究が開始されている。しかしながら、スペースプレーンの実現には技術的に多くの課題が山皘 しており、閶発のための具体的方策について、科学技術庁・研究開発局长の諮問機関である「スベー


の一現として「スベースブレーン開発野问铜查」を日本航空宇宙工業会に委託し、調查埌告著をとり まとめている。これらの答申の中て、超耐熱材料が、機体系、推進系双方にとって最も重要な基盤技 術の一つであると述べられている。

スベースブレーンは、新しいタイプの空気吸込み式エンジンを用いるので、大気图脱出に至る兆行 経路がロケットの場合とは全く異なり、加速する為に、大気中での辰時間にわたる極超音速我行が必 要となる。このため、機体やエンジンは激しい加熱を受け、超高温に達するので、燃料である波体水 菜を用いて冷却しなければならない。従って、機体外面あるいは燃焼室内面とその泠却面との間の 著しい温度差により、大きな熱伈力が発生する。更に、数百回の兆行に耐える耐久性も琶求されるの で、従来の材料をこれらの部材に適用することは困難である。このように、スベースプレーンの実現

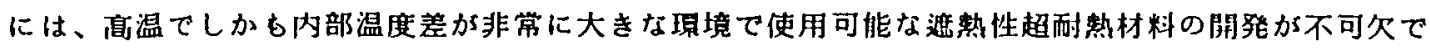
あり、米国のNAS P計画でる、このような材料開発は重要課題となっている。 
このような要求に甚づき、わが国で『傾斜機能材料』という全く新しい複合材料の概念が生まれた。 2. 傾科機能材料の概念

热纫力緩和を例にとった倾斜機能材料の概念の模式図をFig.1 に示す。これは、数千度の高温力゙ に接する面にはセラミックスを配して耐熱性を与え、冷却を行う面には金属材料を配して熱伝等性と 機械的強度を与えて、その間の組成や組織 及び 空孔率が最適な分布になるように材料の合成を行う ことにより熱心力を積極的に緩和させようというものである。

このように、材料を構成する要索（金属、セラミックス、プラスチックス、䋐維、望孔 等）の分 死を速続的に、かつ使用現境に合わせて適切に制御することによって得られる機能の偭斜した材料を 傾斜機能材料（Functionally Gradient Material；F GM）と名付けた。この㑯斜機能材料の概念 は、界面に起因する多くの問題の解決手段として、また、傾斜組成それ自身が新しい機能を発㨁する 材料として然限の可能性を秘めており、航空宇宙用材料に限らす、核虽合分野、裺気的、光学的な特 性が妿求されるエレクトロニクス分野、医療分野などへの幅広い応用が期待される。

3. 㑯斜機能材料開発プロジェクトの紹介

1987 年度より科学技術振興調整䐝のもとで「熱応力緩和のための倾斜機拕材料間発の基盤技術に関 する研究」が開始された”。研究開発は、F1g.2 のような、材料設計、满造制御 及び 特性評洒の三 部門の有機的速排のもとに推進される。本研究は、最高表面温度 $2000 \mathrm{~K}$ 、温度落差 $1000 \mathrm{~K}$ という現 境で使用可能な材料の創製のための基盤技術の確立を目標とする。砳究期間は1987年度からの第I期 3 力年と 1990 年度からの第 II 期 2 力年の計 5 力年間を予定しており、第 I 期では厚さ 1 〜 $10 \mathrm{~mm}$ 、 直径 $30 \mathrm{~mm}$ の小型試験片、第 $\mathrm{I}$ 期では同じ厚さで $300 \mathrm{~mm}$ 角の板款の合成を目指している。

4. 材料設計部門の進捗状況

Fig. 3 は、材料設計の為に開発する逆钤計システムのフローである。形状や使用条件等を含む材料


布を仮定して、材料内部の物性值分有を推定する。これを用いて使用条件下での温度や熱応力の分布 を計算し、仕様を満足するか否加の判定を行う。このブロセスを、最適なミクロ措造分布が得られる まで繰り返し、得られた樶適設計結果を、構造制御部門へ提供する。

次に、本システムによる㜣焼器材料の設計例を示す2!。解析モデルとしてはFig.4に示すように、 内半径 $95 \mathrm{~mm}$ 、板厚 $10 \mathrm{~mm}$ の内筒が、内表面を $1500 \mathrm{~K}$ に加熟され、外表面を $300 \mathrm{~K}$ に冷却された 場合を想定し、発生する熱応力分布に急峻な変化がないように設計した。幸材の組合せは、自己発熱 反応法により試作研觉が行われている Cu-TiB 2 系とした。結果をFig.5 に示す。Fig.5(a) に示すよ うに、TiB 2 と $\mathrm{Cu}$ を張り合わせた二層材や中間層をるつ三層材は、接合面に引張応力゙生ずるので㔀

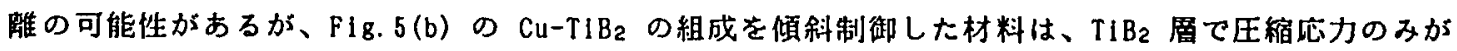
発生するため、熱㐫力破壊を生じにくくなっている。

本計算例では、材料内部の物性值分布の推定に、数種の均質混合材の测定結果との一致が確認され ている既存の混合則を用いた。しかしながら、傾斜機能材料は従来の均筫材料と微構造が全く異なる ため、既存の混合則をそのまま適用するには問題がある。また、統べての材料組合せと種々の混合比 に対する物性值测定は、膨大な時間がかかり、不可能である。このため、東京工業大学で、傾斜機能 材料のミク口組織を考虑した、多相混合系に対する物性值推定モデルを開発中である。この推定法の 確立により、更に材料設計の最道化、省力化が可能となる。

5. 構造制御部門における研究進捗状况

合成技術については、種々の研究成果のうちのいくつかを紹介するう。

物理化学蒸着融合法では、基硞研究は、金属材料技術研究所で物理蒸着法が、東北大学 金属材料研

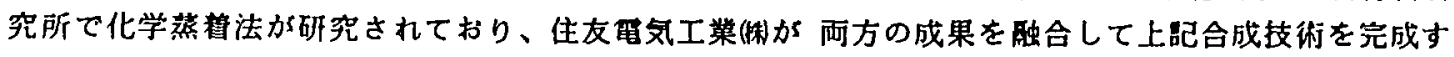


る。本方法を用いて、C/C コンポジットを基材とし、低温侧は物理蒸着法により Ti-TiC 系偭斜組成 層を、高温侧は化学蒸着法により C-SiC 系傾斜組成層を形成して、金属との接合が可能で、かつ高温 での耐酸化性に佃れた小型傾斜機能材料が合成された。

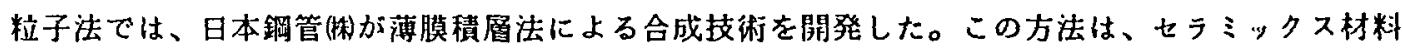
と金属材料の原料粉末を混合してスラリーを作り、ドクターブレード法により薄膜（グリーンシート

）を作成し、積㒶烧結して傾斜機能材料を合成しようとするものである。すでに、Ni-Z r 02 乔の小型 傾斜機能材料が合成されている。

浴射法では、新日本製践俐が減压ブラズマ溶射法により、1つのブラズマガンから發生するブラズ マシェット中にセラミックス粉末と金属粉末を送給制御して、傾斜組成单を作成する技術を確立した。 これは、1つのブラズマガンに 4 方向から粉末を投入する4ポート式減压同時溶射法である。

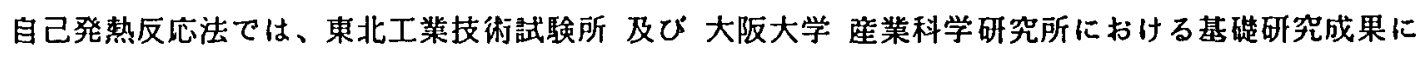
基づいて、大型、複雑形状化技術の開発を川崎重工業㑣が担当している。現在、H I Pによる TiAl一 $\mathrm{MOSi}_{2}$ 系傾科機能材料の合成法を研究している。

上貶の㗅究では、いずれも本プロジェクト第 $\mathrm{I}$ 期の目標である直径 $30 \mathrm{~mm}$ 程度の試験片合成に成功

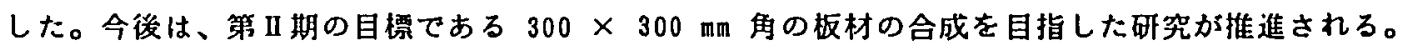

6. 特性評洒部門の研究進捗状㫛

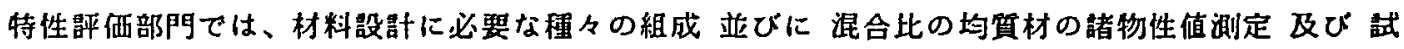

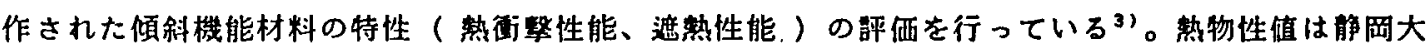
学が、機械的特性は東北大学が中心となって評価を行っている。

航空宇宙技術刮究所では、遮熱性能評価を担当しており、宇宙往逼機への適用を念頭において、各

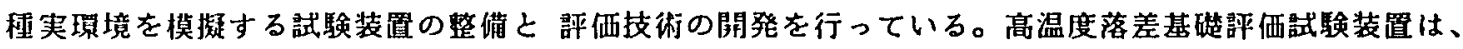
開発目標である表面温度 $2000 \mathrm{~K}$ 、温度落差 $1000 \mathrm{~K}$ の試呀条件を発生でき、最大熱負荷 $5 \mathrm{MW} / \mathrm{m}^{2}$ の 山力が可拕で、試料の遮熱性能、耐熱性能 及び熱疲労特性の評価に使用されている。空力加熱場評

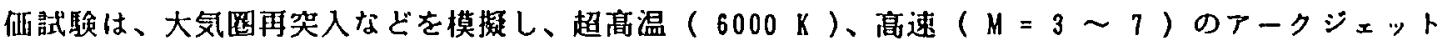
中での耐熱性のほか、耐酸化性、再使用性などにっいて評価する。高速回転加熱場評佂試験は、超音 速ターボエンジンのタービンブレードの作野状態を模擬する。第 1 段階として、Fig. 6 に示すように、

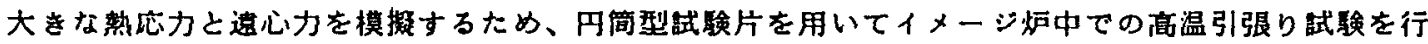
った。今後は、ディスクに円筒型試検片を取り付け、高温ガス中で円简内部を冷却して、使用現填で の評洒を実施する計画である。

以上、各種模擬実愣境評洒試験法が確立されつつあるが、得られた成果は、傾斜機能材料の開発の みならず、苛酷な現境下で使用される種々の材料開発に大きな貢献をするるのと㸝待される。

本プロジェクトに奇せる内外の関心が極めて高いのて、傾斜機能材料研究の輪を大きく広げるため、 1988年 2月倾斜機能材料研究会（事稀局は(社)未眿科学技術劦会に圈く）を発足させた。本研究会 は、ワークショップやシンボジゥムの開催、あるいは刊行物等の発行により、㑯科機能材料䂧究をよ り一層拡大するため活動してゅく。

\section{参考文献}

1) 昭和61年度科学技術振興铜整暂調查報告晴，科学技術庁·研究開発局，1987年 3月

2）平野 徹；材料力学諈演会前刷集，1986年11月

3）第 3 回㑯斜機能材料シンポジゥム講演論文果, 傾斜機能材料研究会, 1989年 9月 


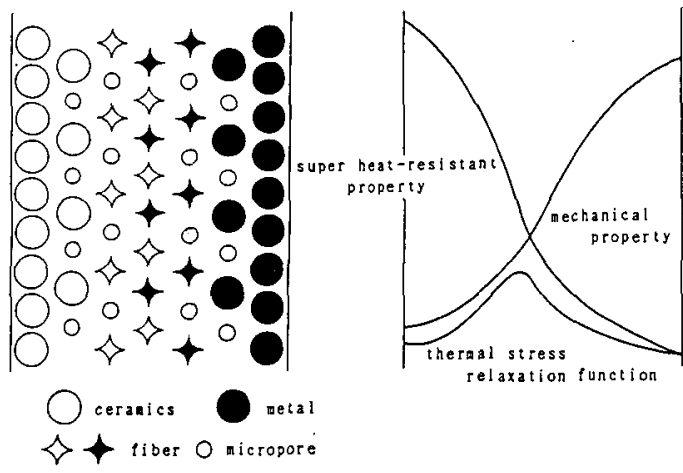

Fig. 1 Concept of functionally gradient material.

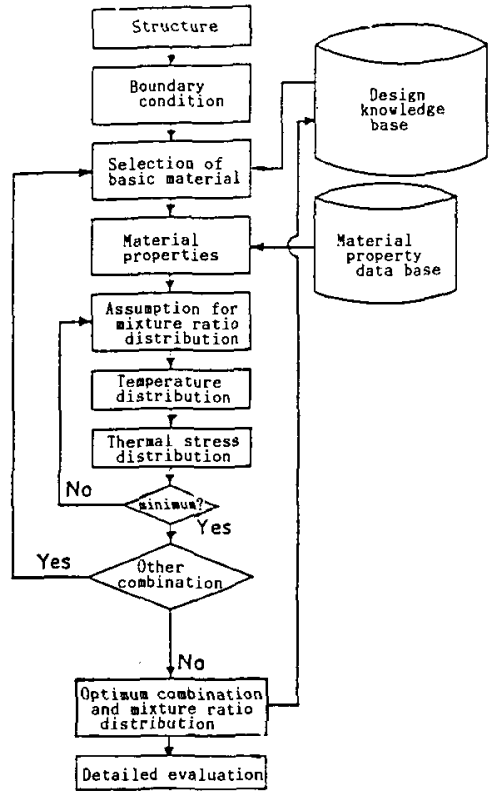

Fig. 3 Inverse design procedure.

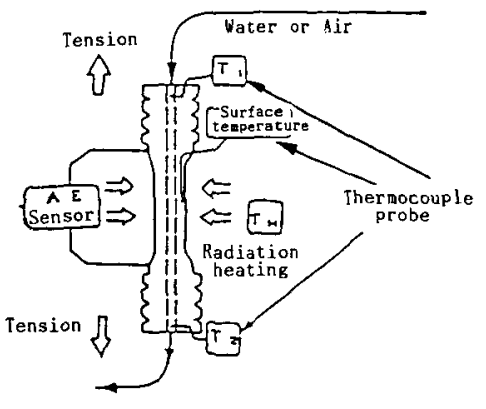

Fig. 6 Schematic of high temperature tension test.

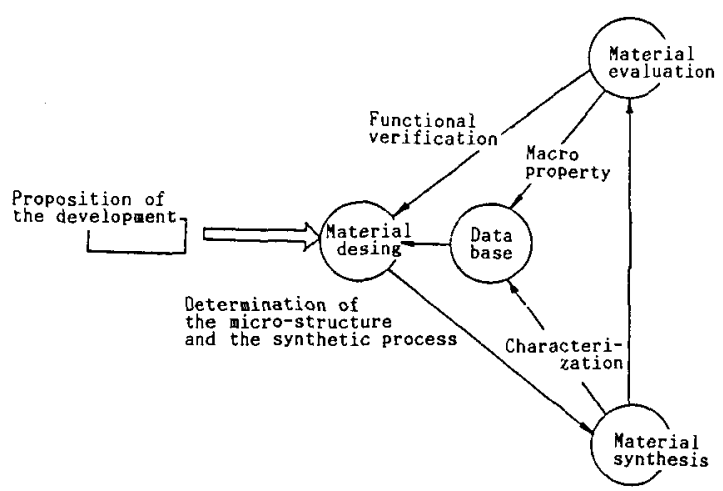

Fig. 2 Research and development system.

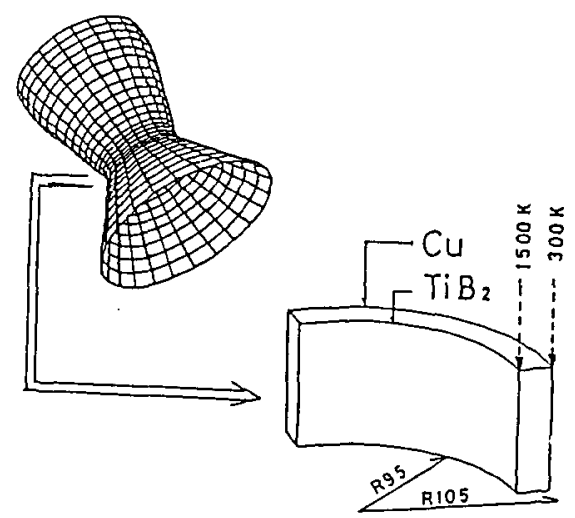

Fig. 4 Thrust chamber model.

(a) 2 plies \begin{tabular}{r|c|c|c|}
\hline $\mathrm{TiB}_{1}-1$ & $\mathrm{Cu}$ \\
\hline
\end{tabular}

(b) 3 plies \begin{tabular}{l}
$\mathrm{TiB}_{2}$ \\
\hline
\end{tabular}

(a)

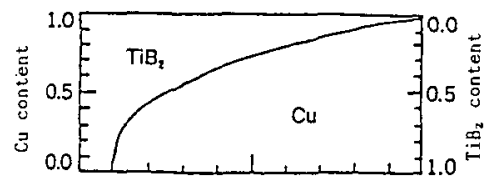

(b)

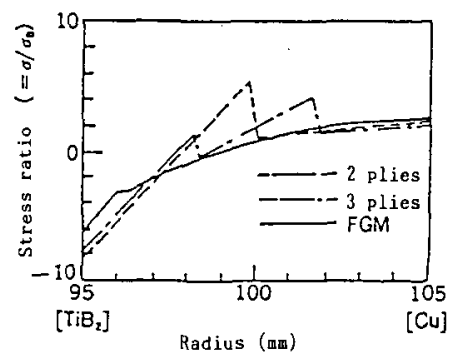

Fig. 5 Distribution of mixture ratio and thermal stress. 